\title{
Isolation of bacteria capable of removing 2-methylisoborneol and effect of cometabolism carbon on biodegradation
}

\author{
Kang Dư ${ }^{1,2}$, Jian Liu $^{{ }^{\dagger}}$, Beihai Zhou ${ }^{1,2}$, Rongfang Yuan ${ }^{1,2}$ \\ ${ }^{1}$ Department of Environmental Engineering, School of Civil and Environmental Engineering, Beijing University of Science and Technology, Beijing 100083, China \\ ${ }^{2}$ Beijing Key Laboratory of Resource-oriented Treatment of Industrial Pollutants, Beijing 100083, China
}

\begin{abstract}
2-Methylisoborneol (2-MIB) is one of typical odorants in potable water sources, which is hardly removed by conventional water treatment process. In this study, three strains capable of removing 2-MIB singly from drinking water were isolated from activated carbon of sand filter. They were identified to be Shinella zoogloeoides, Bacillus idriensis and Chitinophagaceae bacterium based on 16S rRNA gene sequence analysis. In mineral salts medium without external carbon source, removal efficiencies of $20 \mu \mathrm{g} / \mathrm{L}$ 2-MIB in three days were $23.3 \%$, 32.9\% and $17.0 \%$ for Shinella zoogloeoides, Bacillus idriensis and Chitinophagaceae bacterium, respectively. The biodegradation of 2-MIB was significantly improved with the presence of cometabolism carbon(glycerol, glucose, etc.). In the period of 20 days, Bacillus idriensis can remove $2 \mathrm{mg} / \mathrm{L} \mathrm{MIB} \mathrm{to} 368.2 \mu \mathrm{g} / \mathrm{L}$ and 315.4 $\mu \mathrm{g} / \mathrm{L}$ in mineral salts medium without and with glycerol respectively. The removal of 2-MIB by Bacillus idriensis was from 2 mg/L to 958.4 $\mu \mathrm{g} / \mathrm{L}$ in Xiba river samples on 15 days.
\end{abstract}

Keywords: Bacillus idriensis, Biodegradation, Chitinophagaceae bacterium, Cometabolism, Shinella zoogloeoides, 2-MIB

\section{Introduction}

Taste and odour (T\&O) causing compounds, in particular, 2-methylisoborneol (2-MIB) and geosmin, are a problem for water authorities as they are recalcitrant to conventional water treatment. Removing $\mathrm{T} \& \mathrm{O}$ compounds from drinking water is a significant challenge for water authorities internationally. 2-MIB is a secondary metabolite produced by members of cyanobacteria and actinomycetes [1-3]. It imparts an earthy/musty odour that can be detected by humans at low nanogram per litre levels.

2-MIB cannot be readily removed by conventional water treatments, therefore advanced treatment processes such as activated carbon adsorption, ozonation and advanced oxidation technologies are required [4-9]. Previous studies indicated that biological treatment could be an alternative method for 2-MIB removal [10-14]. Several studies have demonstrated bacterial degradation of 2-MIB, although intermediates and products have in most cases not been identified and where identified have not been particularly well documented. In 1988, it was reported for the first time that microorganisms could be used for biodegrading 2-MIB. Yagi et al. seeded GAC (granular active carbon) filter columns with a bought bacterium of Bacillus subtilis [15]. 2.8 L aqueous solution with 2-MIB concentration of $1.6 \mathrm{mg} / \mathrm{L}$ and $1.8 \mathrm{mg} / \mathrm{L}$ was carried out through the column, then 2-MIB concentrations in the effluent were less than 0.06 and $0.16 \mathrm{mg} / \mathrm{L}$, respectively. In result, $56 \%$ of $2-\mathrm{MIB}$ was biodegraded compared with control without bacterium. In the same year, Izaguirre et al. reported 2-MIB can be used as the sole carbon source to be biodegraded by microorganisms [16]. 2-MIB of mg/L magnitude can be removed in 86-91 days by compound bacteria enriched from a lake; $10 \mu \mathrm{g} / \mathrm{L}$ magnitude of 2-MIB can be removed in 11-16 days by these compound bacteria in the sterilized lake water added 2-MIB. Bacillus fusiformis and $B$. sphaericus isolated from lake water were capable of decreasing 2-MIB at $\mathrm{mg} / \mathrm{L}$ and $\mathrm{ng} / \mathrm{L}$ levels to the concentration below odor threshold concentration (OTC) [17]. B. subtilis isolated from biological activated carbon filter was capable of removing 2-MIB at $\mathrm{mg} / \mathrm{L}$ level [18]. In addition, Candida spp. isolated from a slow sand filter [19] and Enterobacter spp. isolated from the backwash water of a pilot biological filter [9] were both identified as 2-MIB degraders. Zhou et al. [20, 21] also reported isolation of Pseudomonas spp. and Flavobacterium spp. from the surface of biological activated carbon.

As yet, no definitive pathways for the biodegradation of 2-MIB have been proposed, although Tanaka et al. [9] were able to identify two possible dehydration products, 2-methylcamphene and 2-methylenebornane. Oikawa et al. [22] confirmed this by excising

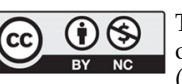

This is an Open Access article distributed under the terms of the Creative Commons Attribution Non-Commercial License (http://creativecommons. org/ licenses/by-nc/3.0/) which permits unrestricted non-commercial use, distribution, and reproduction in any medium, provided the original work is properly cited.
Received December 23, 2015 Accepted April 9, 2016

${ }^{\dagger}$ Corresponding author

Email: chatte27@126.com

Tel: +86-010-62333292 Fax: +86-010-62333292 
the entire cam operon from a camphor degrading Pseudomonas putida, where its subsequent transformation into Escherichia coli demonstrated the acquired ability of that E. coli to degrade 2-MIB. To further elucidate the kinetics and products of 2-MIB biodegradation, it is necessary to isolate single bacterium with the ability to degrade 2-MIB. The objectives of this study focused on the isolation and identification of 2-MIB degraders, examination of 2-MIB degradation performances and optimization of degradation efficiency affecting factors.

\section{Materials and Methods}

\subsection{Materials}

Solid 2-MIB (98\%) used in this study was obtained from Wako Pure Chemicals, Ltd. (Osaka, Japan). Sterile 2-MIB solution (20 $\mathrm{mg} / \mathrm{L}$ ) was prepared by dissolving 2-MIB in Ultra-pure water treated by a Milli-Q system (Millipore Pty Ltd., USA). The solution was then filtered through a sterile $0.22 \mu \mathrm{m}$-pore-size micro porous membrane (MPM) and stored in fridge at $4^{\circ} \mathrm{C}$ before use.

The glassware was washed three times with Ultra-pure water, and all of the glasswares and Ultra-pure water were sterilized at $121^{\circ} \mathrm{C}$ for $30 \mathrm{~min}$ before use.

\subsection{Enrichment Procedures}

Enrichment of 2-MIB degraders was conducted with a mineral salts medium (MSM, $\mathrm{NH}_{4} \mathrm{NO}_{3} 0.1 \%, \mathrm{~K}_{2} \mathrm{HPO}_{4} 0.1 \%, \mathrm{MgSO}_{4} 7 \mathrm{H}_{2} \mathrm{O}$ $0.05 \%, \mathrm{KCl} 0.02 \%(\mathrm{~W} / \mathrm{V}), \mathrm{pH}$ ) as reported by Tanaka et al. [9]. Portions of $100 \mathrm{~mL}$ MSM were placed in $250 \mathrm{~mL}$ Erlenmeyer flask sealed with absorbent gauze and then sterilized at $121^{\circ} \mathrm{C}$ for 30 min. Activated carbon samples were obtained from a carbon filter of a water plant in Beijing, and stored in the bottle containing the influent of the filter at $4^{\circ} \mathrm{C}$. About $5.0 \mathrm{~g}$ carbon was added into $10 \mathrm{~mL}$ sterile PBS buffer ( $0.1 \mathrm{~mol} / \mathrm{L})$. The buffer was shaken vigorously for $15 \mathrm{~min}$.

The culture of PBS buffer for inoculation was poured into the Erlenmeyer flask filled with $100 \mathrm{~mL}$ MSM. The 2-MIB solution was spiked through the sterile $0.22 \mu \mathrm{m}$ pore-size MPM. The initial concentration of 2-MIB in MSM was controlled at $100 \mathrm{ng} / \mathrm{L}$. The flasks were then covered with sealing film $(12 \times 12 \mathrm{~cm}$, Solarbio, Beijing, China) and rotated in an incubator shaker at $30^{\circ} \mathrm{C}$ and $120 \mathrm{r} / \mathrm{min}$ for 5 days. Ten percent of the MSM culture was spiked into another $100 \mathrm{~mL}$ MSM to select 2-MIB degraders, and incubated repeatedly with the increase of 2-MIB concentration $(200 \mathrm{ng} / \mathrm{L}$, $500 \mathrm{ng} / \mathrm{L}, 1 \mu \mathrm{g} / \mathrm{L}, 5 \mu \mathrm{g} / \mathrm{L}, 10 \mu \mathrm{g} / \mathrm{L}$ and $20 \mu \mathrm{g} / \mathrm{L})$. Experimental operation was performed in a sterile operating station.

\subsection{Isolation of 2-MIB Degraders}

For isolation of 2-MIB degraders, LB agar medium (peptone 1\%, yeast extract powder $0.5 \%$, NaCl $0.5 \%$, agar $1.5 \%(\mathrm{~W} / \mathrm{V}), \mathrm{pH} 7)$ was supplemented and autoclaved [21]. Followed by cooling to about $40^{\circ} \mathrm{C}$ the medium was poured into $90 \mathrm{~mm}$ vitreous plates. After application of $1 \mathrm{~mL}$ cultured MSM on LB agar medium in triplicate, these plates were covered with the lids, and sealed tightly. They were placed upside down and incubated at $30^{\circ} \mathrm{C}$ for 2 days. Various cultures were streaked onto the $\mathrm{LB}$ agar medium at least twice for purification. Three pure strains were isolated. The pure cultures were dissolved in several vials of $1 \mathrm{~mL}$ sterile PBS buffer (0.02 mol/L, pH 7), and then centrifuged at 12,000 $\mathrm{r} / \mathrm{min}$ for $3 \mathrm{~min}$. The cells in each vial were washed twice with $1 \mathrm{~mL}$ sterile PBS buffer, and then stored at $4^{\circ} \mathrm{C}$ before 2-MIB degradation tests were conducted. Analysis of physio-biochemistry for 2-MIB degraders was carried out to investigate the characteristics of biological metabolism.

\subsection{Identification of Bacteria}

The purified isolates from various cultures were identified by a commercial laboratory, TaKaRa Biological Company (China). The 16S ribosomal RNA (rRNA) gene was PCR-amplified from plasmid DNA isolated from the enriched culture. The purified culture of $10 \mu \mathrm{L}$ was spiked into the sterile water, and then denatured at $99^{\circ} \mathrm{C}$ followed by centrifugation. The supernatant was taken as the template strand. The fragments of target gene were amplified using Takara 16S rRNA Bacterial Identification PCR Kit(Code No.D310). PCR cycling parameters used were as follows: $1 \mu \mathrm{L}$ of masterready reagent at $94^{\circ} \mathrm{C}$ for $5 \mathrm{~min}$ and circulated one time; $25 \mu \mathrm{L}$ of PCR premix at $94^{\circ} \mathrm{C}$ for $1 \mathrm{~min}, 0.5 \mu \mathrm{L}$ of forward primer $(20 \mathrm{pmol} / \mu \mathrm{L})$ at $55^{\circ} \mathrm{C}$ for $1 \mathrm{~min}, 0.5 \mu \mathrm{L}$ of reverse primer 2 at $72^{\circ} \mathrm{C}$ for $1.5 \mathrm{~min}$, and circulated for 30 times; $23 \mu \mathrm{L}$ of $16 \mathrm{~S}$-free $\mathrm{H} 2 \mathrm{O}$ at $72^{\circ} \mathrm{C}$ for $5 \mathrm{~min}$, and circulated one time. Five micro liters of amplified sample was used to conduct an Agarose Gel Electrophoresis (AGE), followed by Gel Extraction Purification using Takara Agarose Gel DNA Purification Kit Ver.2.0(Code No.DV805A). Sequence analysis was performed with Seq Forward, Seq Reverse and Seq Internal as the primers. Sequence similarity searches were conducted using the National Center for Biotechnology Information BLAST network service (Blastn). Similar sequences, from previously cultured bacteria, were obtained from GenBank and aligned against the DNA sequences of strain 1 to strain 3 .

\subsection{Degradation Performance of Bacteria}

The pretreatment of bacteria was continuous culture in the MSM with $20 \mu \mathrm{g} / \mathrm{L}$ 2-MIB, and enrichment culture in LB medium. Cell suspensions was taken under the conditions of $25{ }^{\circ} \mathrm{C}$ and 5000 $\mathrm{r} / \mathrm{min}$ for $5 \mathrm{~min}$. Centrifugal sedimentation which full of bacteria was washed by ultra-pure water under the same conditions for 3 times. Bacteria liquid was diluted to OD600 of 1. All of the glasswares, ultra-pure water and the centrifuge tube were sterilized at $121^{\circ} \mathrm{C}$ for $30 \mathrm{~min}$ before use.

The sterilized medium used for 2-MIB degraders was MSM containing 2-MIB at an initial dose of $20 \mu \mathrm{g} / \mathrm{L}$.Portions of the $100 \mathrm{~mL}$ medium were placed in $250 \mathrm{~mL}$ Erlenmeyer flask and sterilized at $121^{\circ} \mathrm{C}$ for $30 \mathrm{~min}$. Active bacteria of the three 2-MIB degraders were inoculated into several flasks. The flasks were tightly capped to prevent loss of 2-MIB through volatilization, and rotated in an incubator shaker at $30^{\circ} \mathrm{C}$ and $120 \mathrm{r} / \mathrm{min}$ for 2 weeks. Samples of $40 \mathrm{~mL}$ were transferred into a cap vials from the Erlenmeyer flask at 2 and 3 days. The samples were filtered through sterile $0.22 \mu \mathrm{m}$-pore-size MPMs to eliminate the cells of 2-MIB degraders, and then transferred $20 \mathrm{~mL}$ into crimp cap vials (total volume $40 \mathrm{~mL}$ ). All these samples were stored 
in dark at $4^{\circ} \mathrm{C}$. The concentration of 2-MIB was determined within 7 days using GC-MS.

The prepared bacterial suspension were added into MSM containing 2-MIB at an initial dose of $20 \mu \mathrm{g} / \mathrm{L}$ and kinds of cometabolism carbon at $0.2 \mathrm{~g} / \mathrm{L}$. These flasks were rotated in an incubator shaker at $30{ }^{\circ} \mathrm{C}$ and $120 \mathrm{r} / \mathrm{min}$ for 2 weeks. Samples of $20 \mathrm{~mL}$ were transferred into a cap vials from the Erlenmeyer flask at 0 and 3 days. The concentration of 2-MIB was determined within 7 days using GC-MS. Similar experiments with optimization of concentrations of cometabolism carbon were also performed.

2-MIB removal experiments with 2-MIB at an initial concentration of $2 \mathrm{mg} / \mathrm{L}$ were carried out in $2000 \mathrm{~mL}$ Erlenmeyer flask with $1000 \mathrm{~mL}$ MSM. The flasks were tightly capped and rotated in an incubator shaker at $30^{\circ} \mathrm{C}$ and $120 \mathrm{r} / \mathrm{min}$ for 20 days. Samples of $40 \mathrm{~mL}$ were transferred into a cap vials from the Erlenmeyer flask at 2, 3, 4, 5, 7, 10, 15, 20 days, respectively. The samples were filtered through sterile $0.22 \mu \mathrm{m}$-pore-size MPMs and then transferred $20 \mathrm{~mL}$ into crimp cap vials. The concentration of 2-MIB and biomass of living bacteria (plate counting) were measured. Similar experiments with 2-MIB removal in river water sample were also carried out. The concentration of 2-MIB and biomass of total bacteria (OD600) were measured.

\subsection{Analytical Method}

The concentration of 2-MIB was determined by headspace solid-phase microextraction (HS-SPME) coupled with GC-MS [21, 23]. The Injection mode was taken by manual injection. Analyses were carried out in a gas chromatograph (Agilent $6890 \mathrm{~N}$ ) coupled to a mass selective detector (Agilent 5975C). The GC was equipped with a capillary column (HP-5 ms, $30 \mathrm{~m}$ by $0.25 \mathrm{~mm}$ by 0.25 $\mu \mathrm{m}$ film thickness, Hewlett-Packard). The column temperature was held at $40^{\circ} \mathrm{C}$ for $2 \mathrm{~min}$, then programmed to increase at $8{ }^{\circ} \mathrm{C} / \mathrm{min}$ to $240^{\circ} \mathrm{C}$, which was held for $5 \mathrm{~min}$. Helium of purity $99.999 \%$ was used as the carrier gas with a column flow rate of $1.0 \mathrm{~mL} / \mathrm{min}$ in constant flow mode. Individual liquid sample $(20 \mathrm{~mL})$ was supplemented with $0.3 \mathrm{~g} / \mathrm{mL} \mathrm{NaCl}$ and incubated in crimp cap vials, then incubated in heating magnetic stirrer at $60^{\circ} \mathrm{C}$ with rotational speed of $1000 \mathrm{r} / \mathrm{min}$. After $50 \mathrm{~min}$ of incubation, SPME fiber was immersed into the headspace of the liquid sample vial for $5 \mathrm{~min}$, which was agitated so that the analyte was absorbed onto the SPME fiber.

Biomass of samples was detected by $\mathrm{OD}_{600}$ or plate counting method (GB/T 5750.12-2006, China). OD $_{600}$ was analyzed by the spectrophotometer DR $5000 \mathrm{HACH}$. The process of plate counting was same as isolation of 2-MIB degraders. The plate with 30-300 colony forming units (CFU) was utilized.

\section{Results and Discussion}

\subsection{Isolation of 2-MIB Degraders}

Three kinds of bacteria, probably remove 2-MIB (designated as S1, S2, and S3), were observed from the agar 72 hours after inoculation. Three degraders were all gram-positive. The colony-forming time of S1 and S2 was about 24 hours, which was faster than S3. The initial formation colonies of S3 is about $1 \mathrm{~mm}$ growing for 3 days. At 6-7 days, Colony morphology changed to flat and with diameter of $3 \mathrm{~mm}$. Micromorphology of degrading bacteria was observed by 100 times oil immersion lens. The logarithmic phase of S3 was bacilli, and stable phase of S3 changed to be cocci. Morphological characteristics and physio-biochemistry of homogenous colonies are summarized in Table 1.

The suspension of each kinds of bacteria were applied to the surface of mineral salts solid medium coated with 2-MIB $(20 \mu \mathrm{g} / \mathrm{L})$ in vitreous plates. Colonies of S2 and S3 could be observed from the medium 7 days after inoculation and they were all $1 \mathrm{~mm}$.

\subsection{Identification and Phylogenetic Analysis of the Bacteria}

The 16S rRNA phylogeny results (Fig. 1) confirmed the placement of these isolates. According to the DNA sequences which were compared with the NCBI Gene Database, the isolated strain of S1 shares 100\% 16SrRNA gene sequence similarity with its nearest relative of Shinella zoogloeoides, while S2 shares $99 \%$ with Bacillus idriensis and S3 shares 98\% with Chitinophagaceae bacterium. It may be concluded that these bacteria may have played a vital role in the biodegradation of 2-MIB within the Erlenmeyer flask. Satoshi Hanada had reported a member of the family Chitinophagaceae isolated from a hot spring [24], and the logarithmic phase of this bacterium was bacilli while stable phase changed to be cocci. That was quite similar with Chitinophagaceae bacterium (S3). This is the first report of these bacteria capable of degrading 2-MIB.

\subsection{Degradation Efficiency for Three Bacteria}

The comparison of the degradation efficiency for three kinds of the bacteria is to examine the biodegradation rate of the same concentration of single bacterial liquid on 2-MIB over a period of time. The experiment indicated that due to the higher concentration of 2-MIB, there is little impact on the changes of its concentration when absorbing 2-MIB, and therefore it is negligible. Since culture temperature and rotation speed are higher, the experiment examined the natural volatilization of 2-MIB with high concentration, in natural loss of $2-\mathrm{MIB}$ at $\mu \mathrm{g} / \mathrm{L}$ level, the average loss

Table 1. Morphological Analysis of Degrading Bacteria

\begin{tabular}{cccc}
\hline Bacterial colony & S-1 & S-2 & S-3 \\
\hline Colony size & $2 \mathrm{~mm}$ & $2-3 \mathrm{~mm}$ & $1-3 \mathrm{~mm}$ \\
Colony color & White & Milky white & Yellow \\
Morphological & semitransparent, minimal elevation, & semitransparent, round with & Smooth, Wet and convex \\
characteristics & round with a glassy surface & smooth edge & Bacilli (Cocci) \\
Single cell shape & Bacilli & Bacilli & $3-4 \mathrm{~d}$ \\
Colony formation time & $2 \mathrm{~d}$ & $2 \mathrm{~d}$ & $\mathrm{G}+$ \\
Gram staining & $\mathrm{G}+$ & $\mathrm{G}+$ & \\
\hline
\end{tabular}






$\longmapsto$

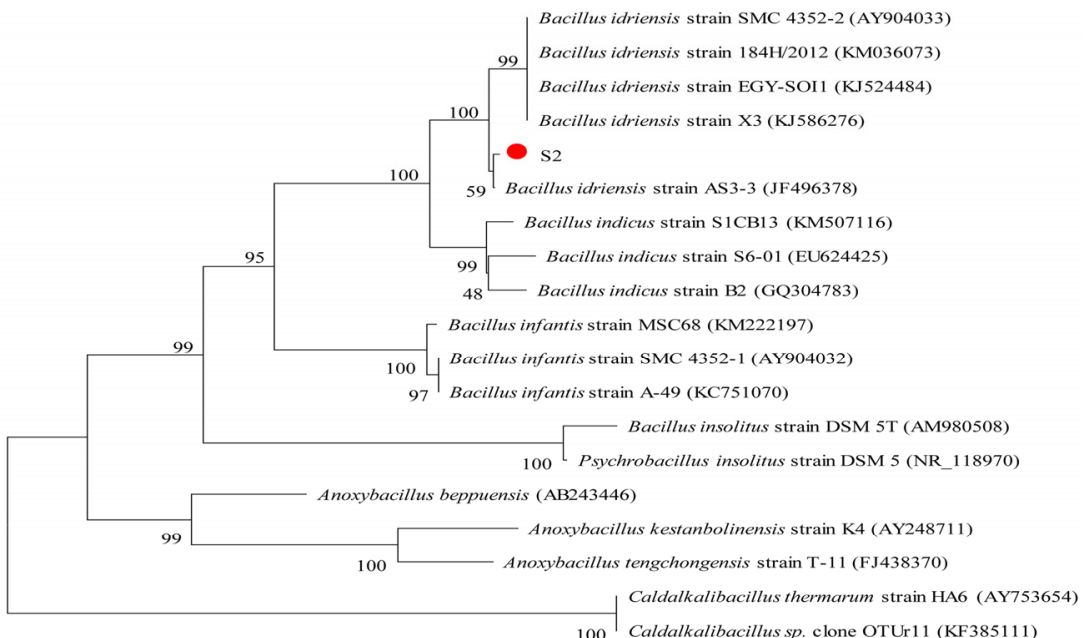

100 Caldalkalibacillussp. clone OTUr11 (KF385111)

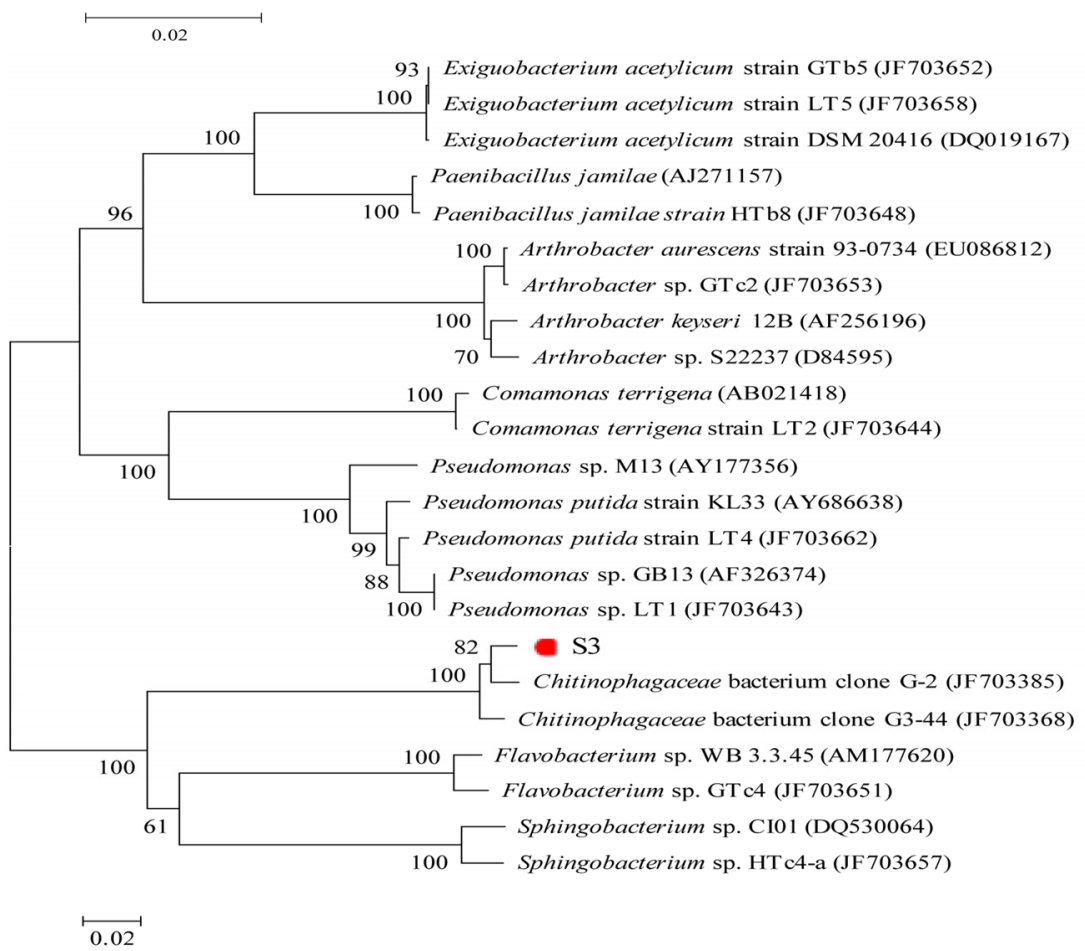

Fig. 1. Neighbor-joining trees showing the phylogenetic relationships of the predominant strains in the isolated culture with the closest-matching species. 


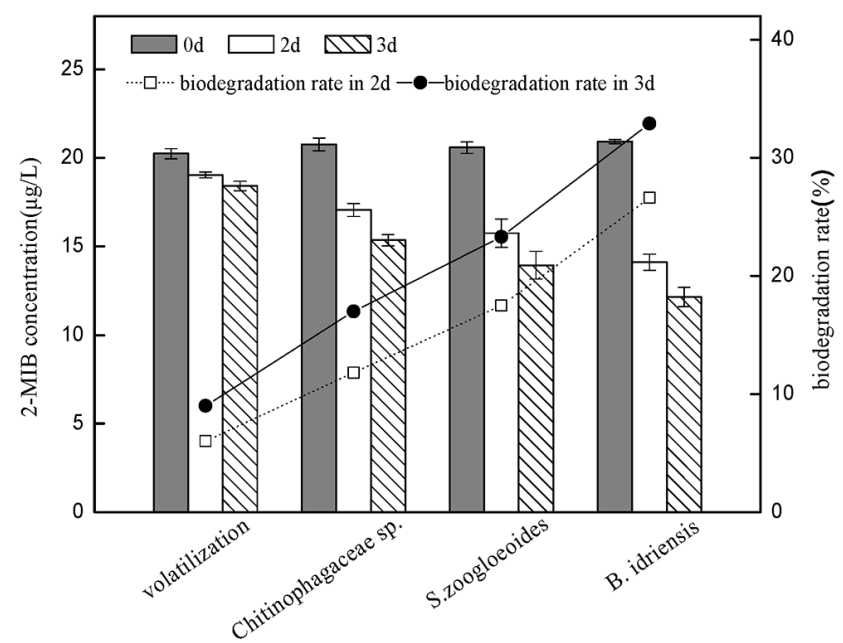

Fig. 2. Degradation efficiency of 2-MIB by three strains.

was about $3 \%$ per $24 \mathrm{~h}$. The comparison of the degradation efficiency of the three kinds of bacterial was as shown in Figure 2. B. idriensis had the highest degradation efficiency, the biodegradable removal rate of $2 \mathrm{~d}$ for $2-\mathrm{MIB}(20 \mu \mathrm{g} / \mathrm{L}$ ) was $26.6 \%$, $3 \mathrm{~d}$ could remove $32.9 \%$ of 2-MIB, the biodegradation removal rate of Shinella zoogloeoides in $3 \mathrm{~d}$ was $23.3 \%$, and the removal rate of Chitinophagaceae bacterium was $17 \%$.

\subsection{Co-metabolic Carbon Source}

\subsubsection{Influence of different carbon sources}

When $B$. idriensis preserved by the glycerol was activated, it was found that $B$. idriensis grew very fast in MSM containing both glycerol and 2-MIB, suggesting that the strain might use glycerol as the carbon source material. There have been a lot of research reports on organic small molecules being degraded as co-metabolic carbon source $[25,26]$. It has been previously reported that the removal rate of degrading bacteria to geosmin had been improved significantly after adding the methanol or ethanol.

In order to investigate the degrading ability of strain to 2-MIB when there was the co-existence of other competing carbon sources, some carbon sources most commonly reported were selected: ethanol, glucose, fructose, sodium acetate, glycerol and yeast extract, their impact on B. idriensis and Chitinophagaceae bacterium degrading 2-MIB was as shown in Fig. 3. Except ethanol, when there is presence of extra carbon sources, the degradation ability of strain to 2-MIB could be improved significantly. Glucose, fructose, sodium acetate, glycerol are the direct carbon sources of small molecules, and are often used to offer energy for bacterial culture. In this study, B. idriensis had higher utilization of the extra carbon sources. When there were glucose, fructose, glycerol and other extra carbon sources, the bacterial growth rate was significantly increased, indicating that these carbon sources can participate in the metabolic activity of growth and reproduction of $B$. idriensis strain. Although the impact of the different external carbon sources on 2-MIB degradation efficiency is measured only at $3 \mathrm{~d}$, but the contrast of the degradation efficiency was sufficient to explain that the glucose, glycerol and other co-metabolic carbon sources
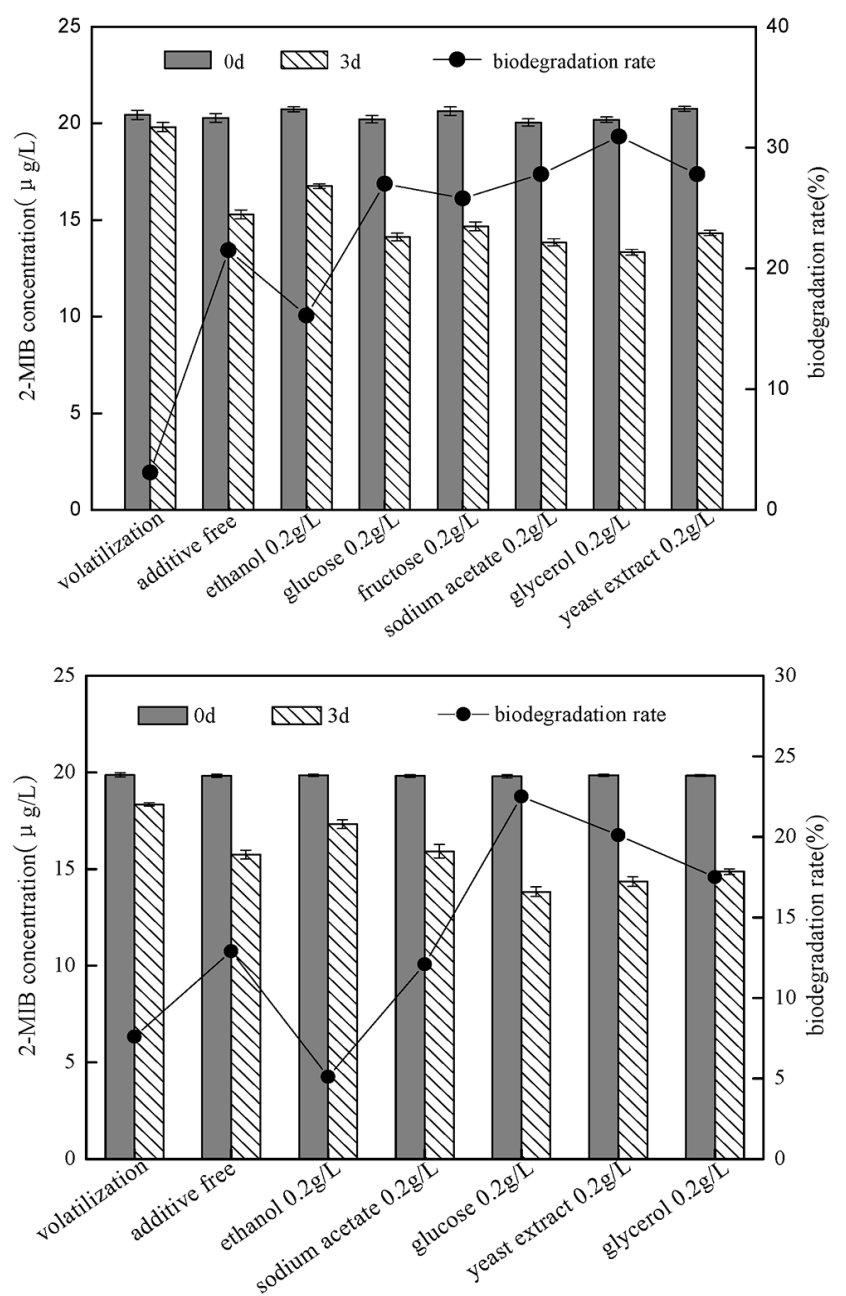

Fig 3. Effect of cometabolism carbon for B. idriensis(up) and Chitinophagaceae bacterium(down).

can directly affect the biodegradation of $B$. idriensis to 2-MIB. Similar to $B$. idriensis, when there is presence of extra carbon sources, the degradation ability of Chitinophagaceae bacterium to 2-MIB could be improved significantly, especially for glucose. Glucose, glycerol and other small molecules of carbon sources can be used directly as a primary energy source for microbial growth to offer the carbon, nitrogen sources and others required by $B$. idriensis and Chitinophagaceae bacterium, thereby improving the thallus growth environment, enhancing the growth rate of the thallus, and it also accelerates the bacteria to produce key enzyme to biodegradate 2-MIB to a certain extent [25], thereby increasing the degrading efficiency of degrading bacteria.

\subsubsection{Influence of different concentrations of co-metabolic carbon sources}

The existence of co-metabolic carbon source could accelerate the growth and reproduction rate of degrading bacteria and improve the biodegradation rate of 2-MIB, therefore, the study examined the impact of different concentrations of glycerol, and glucose co-existing with 2-MIB on thallus growth and biodegradation rate. 
The study respectively investigated the changes of thallus growth and 2-MIB biodegradable removal rate when 2-MIB (20 $\mu \mathrm{g} / \mathrm{L})$ coexisting with glycerol or glucose with the final concentrations of $0.05 \mathrm{~g} / \mathrm{L}, 0.1 \mathrm{~g} / \mathrm{L}, 0.2 \mathrm{~g} / \mathrm{L}, 0.5 \mathrm{~g} / \mathrm{L}, 1 \mathrm{~g} / \mathrm{L}, 2 \mathrm{~g} / \mathrm{L}$, and the results were as shown in Fig. 4.

When the external carbon source of glucose coexisted with 2-MIB, the growth rate of $B$. Idriensis had been significantly improved. With the increasing glucose concentration, the thallus growth rate was also gradually increased. It indicated that glucose content was positively correlated to slow growth of bacteria. Meanwhile, when there was glucose, the biodegradable removal of 2-MIB was also improved to some extent. When glucose content was $0.5 \mathrm{~g} / \mathrm{L}$, the biodegradation rate of $2-\mathrm{MIB}$ reached a peak. When there was higher concentrations of glucose, its impact on biodegradation rate was little or tended to decrease. It can be concluded that when different glucose concentrations coexist with 2-MIB at 0.05-2 g/L, the thallus growth rate and 2-MIB degradation rate were increased, and there was the highest biodegradation rate of $2-\mathrm{MIB}$ in the concentration range of $0.2-1 \mathrm{~g} / \mathrm{L}$.
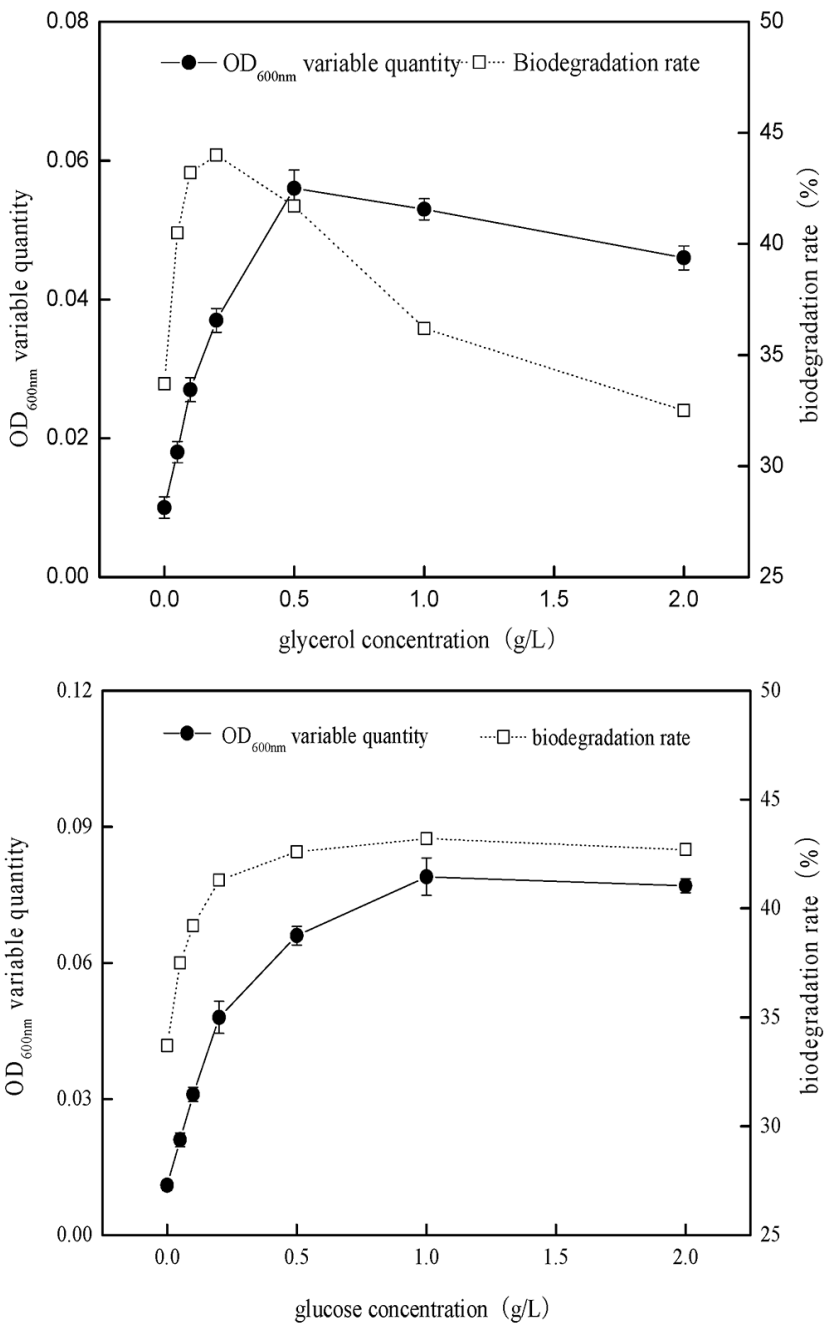

Fig. 4. Effect of different concentrations of cometabolism carbon to B. Idriensis.
When glycerol coexists with 2-MIB, thallus growth rate had also been significantly improved, indicating that different concentrations of glycerol had the promoting effect on thallus growth. However, when there was the glycerol with the concentration of up to 1-2 g/L, the promotion to biodegradation of 2-MIB is not obvious, on the contrary, it was the suppressed compared to a concentration of $0.2 \mathrm{~g} / \mathrm{L}$, and the growth rate of thallus is slightly lower when glycerol concentration is higher than $1 \mathrm{~g} / \mathrm{L}$, indicating that the existence of the high concentrations of glycerol is inappropriate for growth of Bacillus and the biodegradation of 2-MIB. The highest removal rate was reached when the concentration of glycerol is in the range of $0.2-0.5 \mathrm{~g} / \mathrm{L}$. The existence of co-metabolic carbon source offers a wealth of nutrients for thallus growth, which to some extent can promote $B$. idriensis to produce enzymes used to degrade 2-MIB, thereby increasing the degradation efficiency to 2-MIB. However, too much external carbon source not only affects the growth rate of the bacteria, but also reduces the enzymatic reaction, which will have a great impact on the biodegradation process to 2-MIB.

\subsubsection{Effect of yeast extract}

Yeast extract is rich in multiple small molecules of amino acids, peptides, nucleotides, vitamins and other natural active ingredients, it can offer not only the energy for the growth of microorganisms, but also the nitrogen, phosphorus and many trace elements for the bacterial synthesis of enzymes and other substances. It was reported that the beef extract is rich in growth factors of various microorganisms, which can vigorously promote biological oxidation and respiration process, and microbial consumption of the substrates.

In order to investigate the impact of yeast extract on degradation of 2-MIB by B. idriensis, yeast extract was added to MSM containing $20 \mu \mathrm{g} / \mathrm{L} 2-\mathrm{MIB}$, which compared with the same concentration of glucose and glycerol under the same condition (Fig. 5). When yeast extract with glucose or glucose were degraded together with 2-MIB, the degradation efficiency was higher than those containing only 2-MIB. The glycerol and glucose were the substances to directly offer energy for the growth of microorganisms, when total amount of glycerol and yeast extract was maintained at the same level, and the degradation efficiency towards 2-MIB was a bit higher than containing only the yeast extract or glycerol, despite the result was not obvious, it was enough to illustrate the yeast extract offered more than the energy substance for biodegradation of 2-MIB. Similarly, when there was co-existence of yeast extract and glucose, the degradation efficiency was slightly higher than containing only yeast extract or glucose, indicating that there was the existence of certain growth factors or growth elements in yeast extract that promoted the synergetic degradation of 2-MIB under the presence of cometabolism carbon source, accelerating the degradation process of B. idriensis towards 2-MIB. For the addition of the yeast extract, it might also contribute to the synthesis of key enzyme for the degradation of 2-MIB; in oligotrophic MSM, there were few trace elements that can offer microbial metabolism and promote the formation of enzymes, while there were rich trace elements in yeast extract required for microbial growth and reproduction, so it was possible to increase the production and activity of the enzymes. The enzyme activity measuring and determination of 

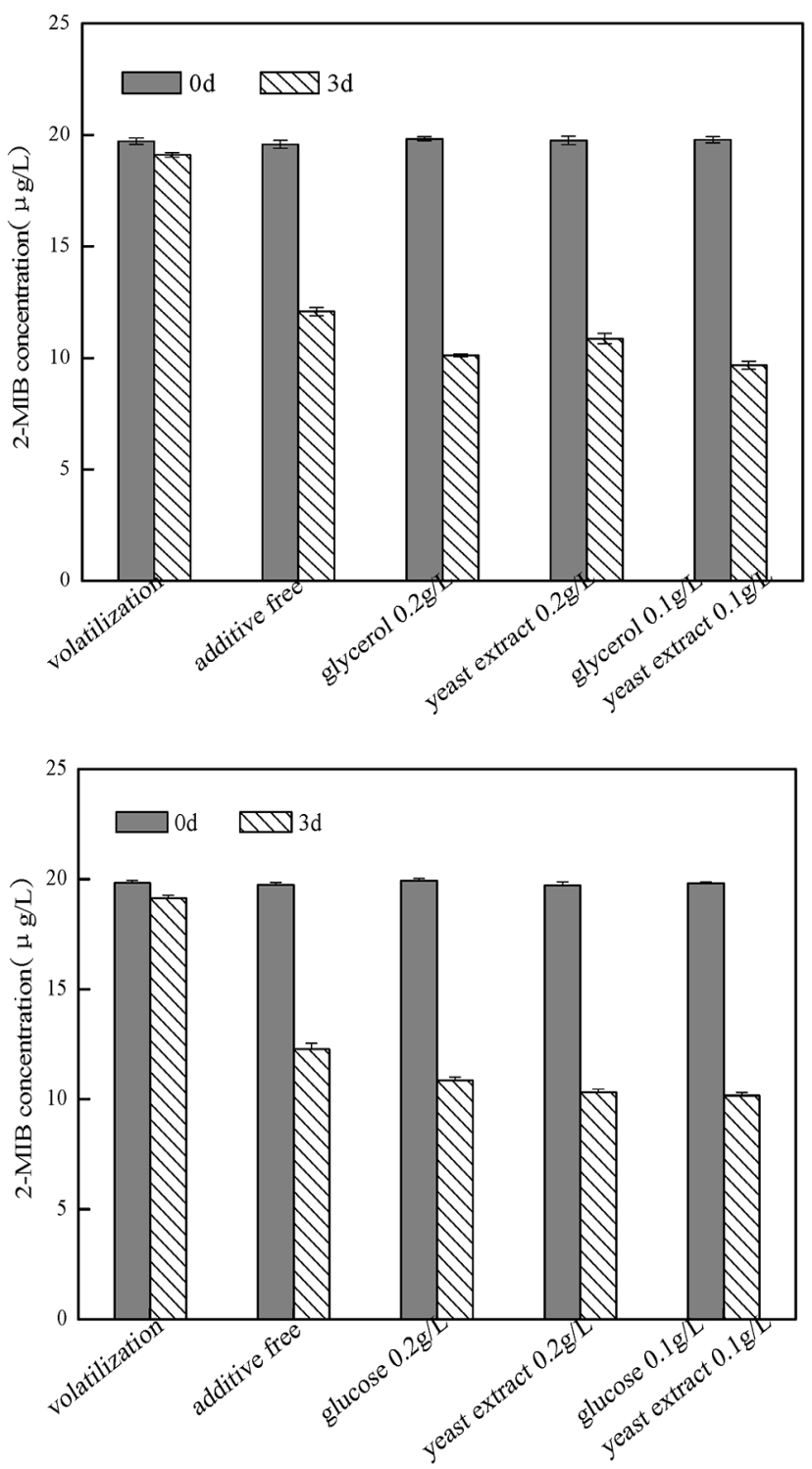

Fig. 5. Biodegradation of 2-MIB in MSM coexisting yeast extract and glucose (glycerol) to $B$. idriensis.

enzyme category and others are needed for the further study of mechanism of yeast extract can improve the degrading activity of bacteria.

\subsection{Growth Curve of $B$. idriensis}

After bacteria $B$. idriensis was added to MSM with high concentration of 2-MIB (Fig. 6), the bacterial growth was slow in the first 1-2 days of the adaptation period, and maybe some bacteria dead because they could not adapt to new oligotrophic environment. Then the number of viable bacteria increased sharply in the logarithmic growth phase from day 3 to day 5 . The stationary phase of the bacteria was from day 6 to day 15, and the stable period was longer, which was helpful for bacteria degradation of 2-MIB; the decline phase was from day 15 to day 20, however,

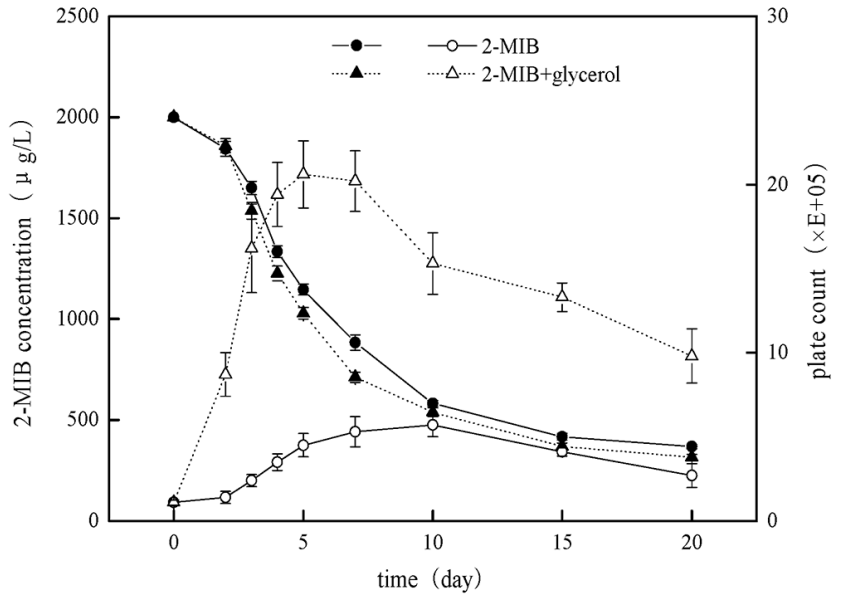

Fig. 6. Concentrations of $2-\mathrm{MIB}$ and growth curve in MSM.

the cardinal number of viable cells was still larger, indicating that $B$. idriensis had stronger viability and metabolism in MSM containing $2 \mathrm{mg} / \mathrm{L}$ of 2 -MIB.

When glycerol $(0.5 \mathrm{~g} / \mathrm{L})$ and 2-MIB exist simultaneously, the growth curve of $B$. Idriensis has some changes, and the adaptation period was one day in advance. The logarithmic growth phase was from day 2 to day 5 , the bacteria growth rate was significantly accelerated than that without the glycerol, and the number of viable cells also increased obviously; the stable period of the bacteria was from day 5 to day 8 , day 8 to day 20 was for decline phase. Despite of the decline phase, there was no significant reduction of the number of viable cells, it was possible because of the presence of glycerol accelerating the growth of bacteria. With the glycerol consumption and the impact of dead cells on the environment, as a result the number of viable cells had a sharp decline on day 8 to day 10, while the thallus was still in the stable period.

In the degradation period of up to 20 days, B. Idriensis can make the degradation of $2 \mathrm{mg} / \mathrm{L} 2-\mathrm{MIB}$ to $368 \mu \mathrm{g} / \mathrm{L}$, showing thalli have stronger tolerance and degradation towards odor substance with super-high concentration. When there is the presence of glycerol, as can be seen from the degradation cycle curve that after the thalli entering into the logarithmic growth phase (2-5 days), its degradation rate towards of 2-MIB is accelerated significantly, when the number of viable cells is significantly reduced, there is no significant change in the degradation rate of the thalli towards 2-MIB, thus it can be inferred that the dramatic decrease of the number of the viable cells on 8-10 days is due to the thallus growth at the beginning mainly depends on glycerol as the direct carbon source substance, when the glycerol consumption in the medium is reduced to a certain level, the thalli begin to take 2-MIB as the carbon source, which may also explain the number of viable cells maintains at a higher level rather than have any significant decrease on day 10 to day 20. However, due to the presence of glycerol, $B$. Idriensis thalli grow vigorously, the continuous microbial secretion of metabolites and disruption of cell death leads to the changes of $\mathrm{pH}$, dissolved oxygen of bacteria liquid, seriously affecting the late biodegradation of $B$. idriensis towards 2-MIB. This also explains the degradation efficiency under 
the presence of glycerol within 7 days is significantly higher than the case of containing only 2-MIB, but there is ultimately little difference in the degradation rate of above two.

\subsection{Biodegradation of 2-MIB in River Water}

In order to investigate 2-MIB biodegradable removal capacity of $B$. idriensis in actual source of drinking water, the researchers took Xiba river water in September and measured its TOC was $8.942 \mathrm{mg} / \mathrm{L}$, BOD was $5.42 \mathrm{mg} / \mathrm{L}$, DO was $8.92 \mathrm{mg} / \mathrm{L}$, NH4+-N was $4.8 \mathrm{mg} / \mathrm{L}$, TN was $26.0 \mathrm{mg} / \mathrm{L}$, TP was $0.27 \mathrm{mg} / \mathrm{L}$ and $\mathrm{pH}$ was 7.2. The river water sample was filtered with a $0.45 \mu \mathrm{m}$ filter membrane and sterilized for 30 minutes at $121^{\circ} \mathrm{C}$. By taking the treated river water sample as the medium, the study investigated the bacteria growth curve of $B$. idriensis under the presence of $2 \mathrm{mg} / \mathrm{L}$ 2-MIB. Fig. 7 is the growth curve of B. idriensis in treated water sample within 10 days. In the river water samples, $B$. idriensis was able to have rapid growth and reproduction, with a shorter adaptation period, and the longer logarithmic growth phase (day 2-day 5), there is no significant change in the thalli after the stable period, indicating that $B$. idriensis can have a stable growth and reproduction in river water samples.

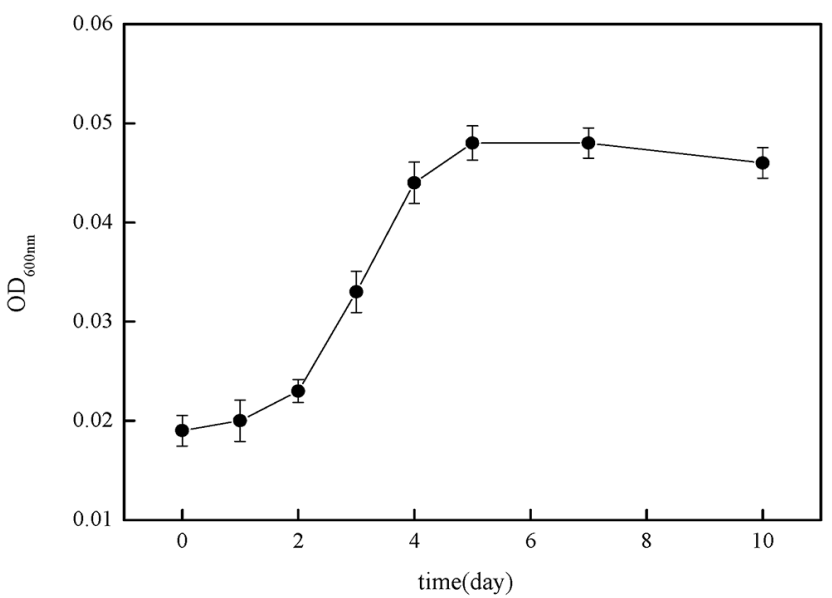

Fig. 7. Growth curve in river water.

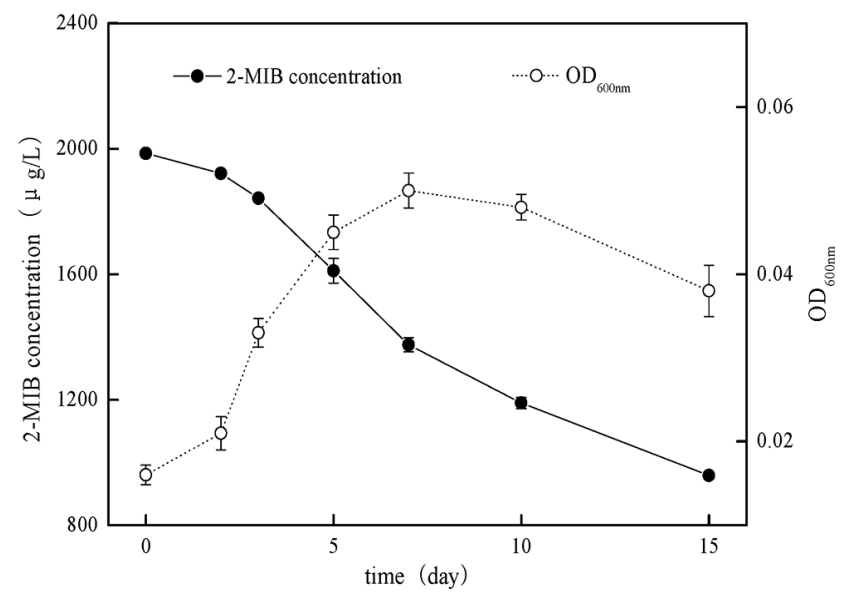

Fig.8. Concentrations of $2-\mathrm{MIB}$ and growth curve in river water with 2-MIB.
When the river water samples contained high concentration of 2-MIB, the degradation process and growth curve of $B$. Idriensis towards 2-MIB is as shown in Fig. 8. Compared with the growth curve without 2-MIB, the bacteria generally grew slowly, indicating that a high concentration of 2-MIB has a certain suppressing effect on $B$. idriensis growth and reproduction. Overall, in the water samples, $B$. idriensis can have the degradation removal of 2-MIB from $2 \mathrm{mg} / \mathrm{L}$ to $958.4 \mu \mathrm{g} / \mathrm{L}$, the degradation efficiency of $B$. idriensis towards 2-MIB is satisfactory.

\section{Conclusions}

Three strains capable of removing 2-MIB singly from drinking water were isolated from activated carbon of sand filter. They were identified to be Shinella zoogloeoides, Bacillus idriensis and Chitinophagaceae bacterium based on 16S rRNA gene sequence analysis. Through the initial discussion on the physiological and biochemical characteristics of three types of bacteria, where the Shinella zoogloeoides and Bacillus idriensis were bacillus, Chitinophagaceae bacterium was bacillus in the logarithmic growth phase, but it was coccus after the stable period. Bacillus idriensis and Chitinophagaceae bacterium could form colonies on inorganic salt medium coated with $20 \mu \mathrm{g} / \mathrm{L} 2-\mathrm{MIB}$. Through evaluation and comparison of degradation efficiency of the three 2-MIB degrading bacteria, where the highest degradation efficiency of all was Bacillus idriensis, removal efficiency of $20 \mu \mathrm{g} / \mathrm{L} 2-\mathrm{MIB}$ in three days was $32.9 \%$.

The effects on degradation efficiency of 2-MIB under the presence of various co-metabolic carbon source were investigated, when there is co-existence of glycerol, yeast extract, glucose, fructose with 2-MIB, the degradation efficiency was improved significantly. The concentration change of co-metabolic carbon source glycerol and glucose had a greater impact on the degradation efficiency of the degrading bacteria, indicating that the co-metabolic carbon source can also promote $B$. idriensis thalli to generate enzyme degrading 2-MIB to some extent in addition to offer rich nutrients for thalli growth.

$B$. Idriensis could have rapid growth and reproduction in the treated river water samples, and could degrade 2-MIB from $2 \mathrm{mg} / \mathrm{L}$ to $958.4 \mu \mathrm{g} / \mathrm{L}$ within 15 days. It indicates that $B$. Idriensis can use 2-MIB to be carbon source material by taking the river water as the medium.

\section{Acknowledgments}

The study was supported by the Natural Science Foundation of China (No. 51178043) and Fundamental Research Funds for the Central Universities (No. FRR-TP-15-047A1).

\section{References}

1. Lior G, Jaap R. 2-Methylisoborneol and geosmin uptake by organic sludge derived from a recirculating aquaculture system. Water Res. 2009;43:474-480. 
2. Westerhoff P, Rodriguez-Hernandez M, Baker L, Sommerfeld M. Seasonal occurrence and degradation of 2-methylisoborneol in water supply reservoirs. Water Res. 2005;39:4899-4912.

3. Cecilie K, Mette HN, Bjarne WS, Warnecke F, Nielsen JL, Jørgensen NOG. Abundance of actinobacteria and production of geosmin and 2-methylisoborneol in Danish streams and fish ponds. FEMS Microbiol. Ecol. 2005;52:265-278.

4. Ismail S. Production of 2-methylisoborneol by Streptomyces violaceusniger and its transformation by selected species of Pseudomonas. J. Basic Microbiol. 2005;45:236-242.

5. Sagehashi M, Shiraishi K, Fujita H, Fujii T, Sakoda A. Adsorptive ozonation of 2-methylisoborneol in natural water with preventing bromate formation. Water Res. 2005;39:3900-3908.

6. Ho L, Hoefel D, Bock F, Saint CP, Newcombe G. Biodegradation rates of 2-methylisoborneol (MIB) and geosmin through sand filters and in bioreactors. Chemosphere 2007;66:2210-2218.

7. Kristin K, Hilmar B, Eckhard W. Photoinitiated oxidation of geosmin and 2-methylisoborneol by irradiation with $254 \mathrm{~nm}$ and $185 \mathrm{~nm}$ UV light. Water Res. 2009;43:2224-2232.

8. Lalezary S, Pirbazari M, McGuire MJ. Oxidation of five earthymusty taste and odor compounds. J. Am. Water Works Ass. 1986;78:62-69.

9. Tanaka A, Oritani T, Uehara F, et al. Biodegradation of a musty odour component, 2-methylisoborneol. Water Res. 1996;30:759-761.

10. Ho L, Newcombe G, Croué JP. Influence of the character of NOM on the ozonation of MIB and geosmin. Water Res. 2002;36:511-518.

11. Izaguirre G, Wolfe RL, Means EG. Degradation of 2-methylisoborneol by aquatic bacteria. Appl. Environ. Microb. 1988;54: 2424-2431.

12. Chance VL, Henry CA, Angela SL. Isolation and characterization of a bacterium capable of removing taste- and odor-causing 2-methylisoborneol from water. Water Res. 2004;38:4135-4142.

13. Richard WE, Peter S. Biotransformations of 2-methylisoborneol by camphor-degrading bacteria. App. Environ. Microb. 2009;75: 583-588.

14. Sumitomo H. Biodegradation of 2-methylisoborneol by gravel sand filtration. Water Sci. Technol. 1992;25:191-198.

15. Yagi M, Nakashima S, Muramoto S. Biological degradation of musty odor compounds, 2-methylisoborneol and geosmin, in a bio-activated carbon filter. Water Sci. Technol. 1988;20:255.

16. Izaguirre G, Wolfe RL, Means EG. Bacterial degradation of 2-methylisoborneol. Water Sci. Technol. 1988;20:205-210.

17. Schumann R, Pendleton P. Dehydration products of 2-methylisoborneol. Water Res. 1997;31:1243-1246.

18. Yagi M, Nakashima S, Muramoto S. Biological degradation of musty odour compounds, 2-methylisoborneol and geosmin, in a bioactivated carbon filter. Water Sci. Technol. 1988;20: 255-260.

19. Sumitomo H. Odor decomposition by the yeast Candida. Water Sci. Technol. 1988;20:157-162.

20. Zhou BH, Wang J, Cai MM, Zhu L, Song WJ. Isolation of a bacterium capable of removing 2-methylisoborneol from water. J. Univ. Sci. Technol. B. 2007;29:227-230

21. Yuan RF, Zhou BH, Shi CH, Yu L, Zhang C, Gu J. Biodegradation of 2-methylisoborneol by bacteria enriched from biological activated carbon. Front. Environ. Sci. Eng. 2012;6:701-710.

22. Oikawa E, Shimizu A, Ishibashi Y. 2-Methylisoborneol degradation by the CAM operon from Pseudomonas putida PpG1. Water Sci. Technol. 1995;31:79-86.

23. Zhong XH, Zhou LH, Yu SB, Xu YH, Qu YB, Su GN. Detection of 2-MIB and GSM in water by HS-SPME-GC-MS. J. Environ. Hyg. 2015;5:279-282.

24. Satoshi H, Hideyuki T, Kazunori N, Kamagata Y. Crenotalea thermophila gen. nov., sp. nov., a member of the family Chitinophagaceae isolated from a hot spring. Int. J. Syst. Evol. Micr. 2014;64:1359-1364.

25. Xie S, Liu JX, Li L, Qiao CL. Biodegradation of malathion by Acinetobacter johnsonii MA19 and optimization of cometabolism substrates. J. Environ. Sci. 2009;21:76-82.

26. Wang SJ, Loh KC, Shao SC. Prediction of critical cell growth behavior of Pseudomonas putida to maximize the cometabolism of 4-chlorophenol with phenol and sodium glutamate as carbon sources. Enzyme Microb. Technol. 2003;32:422-430. 